Info Artikel:

Diterima: 02/11/2018

\title{
Need analysis of English skill for business materials
}

\author{
Rama Dwi Putrilani ${ }^{1}$, Mukhaiyar ${ }^{2}$, Refnaldi ${ }^{3}$ \\ ${ }^{123}$ Universitas Negeri Padang
}

\begin{abstract}
Need analysis is process collecting the information from stakeholder (Educational Institution and Company) about the learners' need. Need analysis is needed before the materials are used. It is done to identify the materials needs the students based on stakeholder's perspectives. It gives us a suitable material for the learners'need and the target need. The aim of this research was to find the English skill most needed for Business materials of Business Administration student at Politeknik Negeri Padang. The type of this research was a survey research. The data were collected through questionnaire and interview. The sources of questionnaire data were 20 students of Business Administration at Politeknik Negeri Padang, 3 lecturers of Business Administration at Politeknik Negeri Padang, 20 staff of Telkom SUMBAR, and 36 staff of Bank Nagari. The sources of interview data were 2 students of Business Administration at Politeknik Negeri Padang, 3 English lecturers of Business Administration at Politeknik Negeri Padang, 1 chief of Business Administration at Politeknik Negeri Padang, 2 staffs of company at Telkom Sumbar, 6 staffs of company at Bank Nagari. The finding of this research shows that the material needed by learners more emphasized on English skill of students ; speaking, listening, and reading.
\end{abstract}

Keywords: material, need analysis

This is an open access article distributed under the Creative Commons Attribution License, which permits unrestricted use,
distribution, and reproduction in any medium, provided the original work is properly cited. C2017 by author.

\section{INTRODUCTION}

Need analysis is absolutely activities of collecting information. Brown (2001: 35) states that need analysis refer to as the activities involved in gathering information that will serve the basis for developing a curriculum that will meet the learning needs of a particular group of students. He provides clearer intention that need analysis is obtained information. It may be used as the foundation for determining the goals and objectives of the course, developing materials and tests as well as deciding the strategies to be applied in the teaching and learning process.

Related to need analysis materials, Dudley-Evans and St.John (2008: 125) state that needs analysis can be used to dig up what the learners are required to master in order to perform the prescribed tasks. It means that the demand of the target situation which requires the students to function effectively in a particular task. Need analysis is a process of collecting information about students' need in order to obtain the criteria materials needed by the students. To achieve this goal, needs analysis need to be connected with the stakeholders in order to obtain information about what skills mostly required at work are.

In addition, the population for need analysis should appropriately to the target need. Richard (2001:57), the target population refers to the people about whom information will be collected. Typically, in language programs these will be language learners or potential language learners, but other are also often involved depending on whether they can provide information useful in meeting the purposes of the needs analysis. They might include policy makers, ministry of education officials, teachers, students, academics, employers, vocational training specialists, parents, influential individuals and pressure groups, academic specialists and community agencies. 
There are variety procedures to get the main information for need analysis. Most of researchers use the procedure questioner and interview to get main information. In development, there are many procedures to get the source information for need analysis. Duddley-Evans and St. John (2008) state that the main data collection method for needs analysis are questionnaires, analysis of authentic spoken and written texts, discussion, structured interview, observation and assessments.

The pieces of needs stated by Brindley then are classified by Hutchinson and Waters (2008: 58-63) into two broad terms; target needs (what the learner needs to do in the target situation) and learning needs (what the learner needs to do in order to learn).

The target needs are closely related to the knowledge and skills that the students have to master so that they are able to perform the prescribed tasks at work. Further, Hutchinson and Waters elaborate the elements of target needs into: 1)Necessities: What is necessary in the learners' use of language? For example, do the learners have to write answers to exam questions? 2)Lacks: what do the learners lack? For example, are there aspects of writing that were not practiced in their previous learning (L1, L2)? 3)Wants: what do the learners wish to learn?

Meanwhile, sorts of knowledge and skills needed for facilitating the students in learning are learning needs. One of Learning needs for ESP class is the materials. The materials in a course function as a source of language, a learning support, motivation, and reference as stated by Dudley-Evans and St.John (2008:170-171). The learners would acquire vocabulary and learn to construct sentences by making use of the words and their structures through materials presented in the class. By presenting attractive and well-designed materials, the teachers could encourage the student to learn.

A study was done by Nofrina Eka Putri (2015) on English Needs Analysis of Management Students of Faculty of Economy of Universitas Negeri Padang. Nofrina Eka Putri (2015) gathered information viewed from target needs, present needs and learning needs. The results of her research showed that in order to perform appropriately at work, the Management students are required to master English especially speaking and listening skills.

Meanwhile, the ESP course at Business Administration at Politeknik Negeri Padang different with need analysis as found by Nofrina Eka Putri (2015). This research was conducted to gather information only viewed from target needs and learning needs. The material needed by learners need and target need more emphasized on activities of speaking, listening, and reading. Thus, the present research was to identify need analysis English skill for Business material used by Business Administration students of Business Administration program at Politeknik Negeri Padang. Therefore, the results can be as an overview in need analysis for future improvement at ESP class.

\section{METODOLOGI}

This research was a survey research intended to identify English skill most needed for Business materials need by students of Business Administration program at Politeknik Negeri Padang are viewed from the participants' point of views. The participants were staffs of Telkom Sumbar and Bank Nagari, students, lecturer, and chief of Business Administration of Business Administration at Politeknik Negeri Padang. The data were collected through questionnaire and interview.

\section{RESULT AND DISCUSSION}

\section{The materials needed by Business Administration students in Business Administration students at Politeknik Negeri Padang.}

The data were taken from need analysis result. Need analysis about the most importance of English skill: speaking, listening, reading and writing. The sources of data were Telkom Sumbar, Bank Nagari, student, lecturer, and chief of Business Administration at Politeknik Padang

Viewed needs, data gather consist of target need and learning need. As stated by Brindley then are classified by Hutchinson and Waters (2008: 58-63) into two broad terms; target needs (what the learner needs to do in the target situation) and learning needs (what the learner needs to do in order to learn). For target need, the data was taken from Telkom Sumbar and Bank Nagari. The data for learning need was taken from Students, lecturers, and chief of Business Administration Politeknik Padang. 
For the detail, it can be seen from the following table:

1.1 Need Analysis

Neeed analysis result

\begin{tabular}{|c|c|c|c|c|c|c|c|c|c|c|}
\hline \multicolumn{11}{|c|}{ Neeed analysis result } \\
\hline & \multirow{7}{*}{ 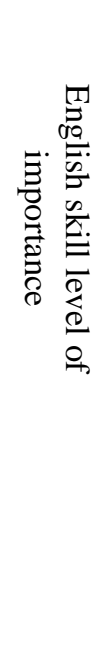 } & \multicolumn{4}{|c|}{ Target need } & \multicolumn{5}{|c|}{ Learning need } \\
\hline & & & 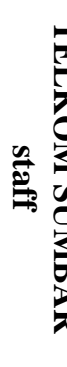 & & & & & & 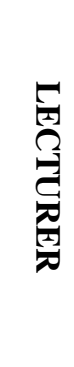 & 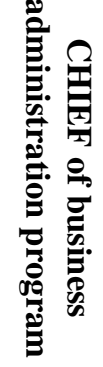 \\
\hline & & $\mathbf{Q}$ & I & Q & I & $\mathbf{Q}$ & I & $\mathbf{Q}$ & I & I \\
\hline Speaking & & $\sqrt{ }$ & $\sqrt{ }$ & $\sqrt{ }$ & $\sqrt{ }$ & $\sqrt{ }$ & $\sqrt{ }$ & $\sqrt{ }$ & $\sqrt{ }$ & $\sqrt{ }$ \\
\hline Listening & & $\sqrt{ }$ & $\sqrt{ }$ & $\sqrt{ }$ & $\sqrt{ }$ & & & & $\sqrt{ }$ & \\
\hline Reading & & & & $\sqrt{ }$ & $\sqrt{ }$ & $\sqrt{ }$ & & $\sqrt{ }$ & & \\
\hline Writing & & & & & & & & & $\sqrt{ }$ & \\
\hline
\end{tabular}

Q: Questionnaire

I:Interview

Speaking, reading, and listening were most needed skill for Business Materials. It was found from survey each stakeholder (speaking, listening, reading and writing. The sources of data were Telkom Sumbar, Bank Nagari, student, lecturer, and chief of Business Administration at Politeknik Padang).

\subsection{Telkom Sumbar Need Skill}

\begin{tabular}{|c|c|c|}
\hline English Skill Ability & $\mathbf{F}$ & Score \\
\hline Speaking & 13 & 65 \\
\hline Listening & 12 & 60 \\
\hline Reading & 4 & 20 \\
\hline Writing & 5 & 25 \\
\hline
\end{tabular}

The data presented that Telkom Sumbar staffs frequently used English through speaking and listening. For speaking, the staffs used English in Negotiations with foreign parties with highly percentage 65\%. Moreover speaking English in conference, at the seminar, in meeting and summit were important for Telkom Sumbar staffs. Meanwhile speaking English on the phone and at an informal event was not important for Telkom Sumbar staffs. Telkom Sumbar staffs highly percentage used English to listen when meeting in abroad and negotiating with foreign parties with $60 \%$.

Based on interview, speaking and listening were required at formal and informal situation in Telkom Sumbar. Speaking and listening which comfortable and can reduce misunderstanding in communication with customers. So, the staffs of Telkom Sumbar need to increase their quality of communication, especially at formal situation. In the Telkom Sumbar, Speaking and listening about marketing, finance, and technical were the main topic at formal situation. For example, speak in promoting the product to clients, and listen the complaint of the customers. Daily conversation informally was also support the staff activities. As explained by staff of Telkom Sumbar :

Formal, topiknya tergantung pada marketing, finance, technical, dan daily conversation juga sepertinya. The translation of statements above:

Formally, the topics are marketing, finance, technical, and may be daily conversation. 


\subsection{Bank Nagari Need Skill}

\begin{tabular}{|c|c|c|}
\hline English Skill Ability & $\mathbf{F}$ & Score \\
\hline Speaking & 30 & 83,3 \\
\hline Listening & 29 & 80,5 \\
\hline Reading & 27 & 75 \\
\hline Writing & 25 & 69,4 \\
\hline
\end{tabular}

The data shown that Bank Nagari staffs were frequently used English through speaking, reading, and listening . Speaking in Conference, at the seminar, on the phone, in meeting, the annual meeting and negotiations with foreign parties with highly percentage 83,3\%. Moreover speaking English at an informal event were important for Bank Nagari staffs. For reading, Bank Nagari staffs have score $75 \%$. The staffs used English to reading the report. And also Bank Nagari staffs important used reading skill to read reference materials, reading messages from e-mail, reading articles from the internet, reading from facsimile, reading the official documents, reading company brochure, reading the company regulations. It was also in order to read the newspaper, reading journals and magazines and reading announcement. The next was listening, Bank Nagari staffs important used listening English in summit, presentation, to the phone, at conference, in annual meeting, when negotiation with foreign parties and to the TV program with highly percentage $80,5 \%$.

Based on interview, Bank Nagari staffs thought English supported activities at the office, more over the activities which have relationship with foreign currency and other bank transaction. There were many term of Bank which used English, so the staff should have understood English. English was required in Bank Nagari even though some division in Bank Nagari did not need skill of English. As stated by one of Bank Nagari staff:

“...tapi dibagian-bagian tertentu dibagian luar negri, bagian legal, bagian valas, bagian remitten tadi ditunjang oleh kemampuan bahasa Inggris..”

The translation of the statements above:

\section{“..In certain division like foreign, legal, foreign currency (fund and treasury), and remitten, English was} needed.

Listening and speaking were most needed by staffs. Formally, they have used English when promote the product of Bank Nagari to foreign. The foreign divisions shared information about tourism to the public.

\subsection{Student Need Skill}

\begin{tabular}{|c|c|c|}
\hline English Skill Ability & $\mathbf{F}$ & Score \\
\hline Speaking & 19 & 100 \\
\hline Listening & 11 & 55 \\
\hline Reading & 15 & 95 \\
\hline Writing & 14 & 70 \\
\hline
\end{tabular}

Speaking skill had highest with $95 \%$ percentage. It means that speaking skill was chosen by the students to be the most needs. Meanwhile, writing was the lowest score 55\%. Reading and writing were higher score than writing. It was added by students of Business Admnistration at Politeknik Negeri Padang, they stated that all skill were important, however the most important skill for Business Administration students was speaking. Speaking was important because the students were required to be expert in public speaking and communicate.

Speaking was the most needs skill. It was added by Nurhajah Saizar, a student of Business Admnistration at Politeknik Negeri Padang, on interview:

Q: Diantara keempat keterampilan Bahasa Inggris (Listening, Speaking, Reading, writing), keterampilan mana yang dianggap paling penting bagi anda? Apa alasannya? Jika keterampilan itu diurutkan dari yang paling penting, bagaimana urutannya?

A: Speaking, listening, dan reading. 


\subsection{Lecturer Need Skill}

\begin{tabular}{|c|c|c|}
\hline English Skill Ability & $\mathbf{F}$ & Score \\
\hline Speaking & 3 & 100 \\
\hline Listening & 2 & 66,6 \\
\hline Reading & 3 & 100 \\
\hline Writing & 2 & 66,6 \\
\hline
\end{tabular}

The data show that speaking skill with $100 \%$ and reading skill with $100 \%$ had higher percentage than the others. It means that speaking skill and reading skill were chosen by the lectures to be the most needs. Meanwhile, the other skill were also importance but not as crucial as speaking skill and reading skill.

All skill were important, however the most important skill for Business Administration students were speaking and writing because they were required to be able to do it in public. Communicating and writing report were main skill for Business Administration students in their job field. Moreover, the others lectures also thinks that the importance of balance between speaking skill with writing skill of the students have. First lecturer stated speaking and writing were most needed. The second lecturer said that all of skills were needed. Based on rank of skill, speaking was most needed. The third lecturer stated that speaking, listening and writing were most needed.

The first lecturer said:

“...Yang paling penting menurut saya itu speaking dan writing...”,

The translation of the statements above:

“...The most important thing I think is speaking and writing...”

The second lecturers said:

“Kalau yang paling penting itu menurut saya berdasarkan urutannya: speaking, writing, reading, listening..."

The translation of the statements above:

"If the most important it seems to me in the order: speaking, writing, reading, listening,.."

The third lecturers said:

"Mungkin speaking kali ya, sama listening, writing..."

The translation of the statements above:

“Maybe speaking, listening, writing,..”

\section{Chief of Business Administration Program}

Based on chief of Business Administration statement, the researcher concluded that the students after graduate from this program were focused on certain important job position such as secretary, administrative staff, supervisor, entrepreneur, and customer service. The positions relate to public services and communication. Such as the secretary, if secretary have meeting or summit with outsider, secretary have to good skill communication exactly in English.

As soon as possible, then after graduated student can competete In MEA (Masyarakat Ekonomi Asean). In Asean Economic Community, they will interact with many people from the domestic and abroad. The Bussiness Administration students have fluently in English is be must. They understand not only the Business concept well, but they expert in English as the medium to express their ideas.

Thus, speaking, listening and reading skill was the most activities that should be emphasized on English for Business materials. According to McDonough, Shaw, Masuhara (2013: 56), in English for Academic Purpose (EAP) program, all language skill are treated, however the language skill needed by the students' are more emphasized.

\section{CONCLUSION}

Based on research, there were 4 skills in English which was required for Business materials. They were speaking, listening, reading, and writing. Speaking, reading and listening were English materials more needed than writing. Speaking was the most skills that should be emphasized on English for Business materials. Telkom Sumbar, Bank Nagari, student, lecturer, and chief of Business Administration program thought that speaking was most needed skill, not only for target need but also learning need. Reading also was English materials required in target need and learning need. But, not all of companies and educational institution needed reading skill. Bank Nagari, student, and lecturer Listening was materials needed by companies only, Telkom Sumbar and Bank 
Nagari. The source of information showed that listening was materials for target need. Writing skill was only needed by lecturer. English lectures are expected to design an English coursebook based on the need analysis, therefore the materials will be suitable for students'age, English proficiency, specialism, and skills needed in real life situation.

Note: Based On Thesis In Titled "Need Analysis Based Evaluation Of English For Business Coursebook For Business Administration Students At Politeknik Negeri Padang"

\section{REFERENCES}

Brindley. G. (1984). Needs Analysis and Objectives Setting in The Adult Migrant Education Service. Sydney: Adult Migrant Education Service

Brown, H. Douglas. (2001). Teaching by Principles; an Interactive Approach to Language Pedagogy. San Fransisco US: Addison Wesley Longman Inc.

Dudley-Evans \& John. (2008). Development in English for Specific Purposes. Cambridge: Cambridge University Press

Hutchinson and Waters, Tom and Alan. (2008). English for specific Purposes_.Cambridge: Cambridge University Press

Putri, Nofrina Eka. (2015) English Need Analysis of Management Students of The Faculty of Economy of Universitas Negeri Padang. Padang: Unpublished Thesis

Richards, Jack C. (2001). Curriculum Development Language Teaching. Cambridge University Press 